\title{
СОЦИАЛЬНО-ЭКОЛОГИЧЕСКОЕ ОБРАЗОВАНИЕ СТУДЕНТОВ: АНЦИПИРОВАННЫЙ АСПЕКТ
}

\section{Шилова В.С.}

НИУ «Белгородский государственный университет», г. Белгород, Российская Федерация

В настоящей статье раскрываются некоторые теоретические предпосылки исследования проблемь ияелей в системе соииальноэкологического образования студентов, раскрывается их сущность, определяются перспективы использования в процессе профессиональной подготовки.

Ключевые слова: ичель, определение понятия в науках; связь с деятельностью и действиями человека; цель педагогической деятельности и общего экологического образования; перспективы исследования.

\section{SOCIO-ENVIRONMENTAL EDUCATION OF STUDENTS: CAPTURAL ASPECT}

\author{
Shilova V.S. \\ National Research University "Belgorod State University", \\ Belgorod, Russian Federation
}

This article reveals some theoretical background to the study of the problem of goals in the system of social and environmental education of students, reveals their essence, identifies prospects for use in the training process.

Keywords: purpose; definition of the concept in the sciences; connection with the activities and actions of a person; the purpose of pedagogical activity and general environmental education; research prospects. 
Решение острых проблем взаимодействия общества с природой требует соответствующей подготовки людей, образованием в этой области учащейся молодежи. Важнейшим в системе социально-экологического образования студентов является его анципированный (целевой) элемент. Рассмотрение его теоретических предпосылок составляет цзель настоящей работы. В связи с этим использовались следующие методы: теоретический анализ и синтез, обобщение, выводы.

В результате было установлено, что категория цели рассматривается разными науками. Философы, например, «цель» определяют как предвосхищение в сознании результата, на достижение которого направлено действие; в качестве мотива цель направляет и регулирует действие, пронизывает практику как внутренний закон, которому человек подчиняет свою волю. Цель определяет активную сторону человеческого сознания, должна находиться в соответствии с объективными законами, реальными возможностями окружающего мира и самого субъекта (И.Т. Фролов) [1]. Социологи раскрывают цель как идеальное предвосхищение результата деятельности, а деятельность - как сложный процесс достижения цели, выбора оптимального пути среди возможных альтернатив и ее планирования. Это один из элементов поведения и сознательной деятельности человека, преобразования окружающего мира (Д.М. Гвишиани, Н.И. Лапин) [2] .

В психологической научной литературе категория цели раскрывается примерно в одном русле. Так, Рубинштейн С.Л. связывает цель с результатом и мотивом деятельности, отдельного действия. Леонтьев А.Н. называет цель главной образующей деятельности и действий, различая при этом цели внешней практической и внутренней деятельности. Он подчеркивает объективный и сознательный характер цели [3].

В целом, несмотря на определение цели с разных позиций, большинство ученых сходится во мнении о том, что цель представляет собой осознаваемый образ предвосхищаемого результата, на достижение которого направлено действие человека. Основой формирования целей человека является его предметно-материальная, трудовая деятельность, направленная на преобразование окружающего мира. 
Цель выступает центральным системообразующим компонентом психологической системы деятельности и проявляется в двух случаях: во-первых, как идеальный и мысленно представляемый ею результат; во-вторых, как уровень достижения, который хочет добиться человек (как задача достичь определенных показателей) (В.Д. Шадриков) [4].

К настоящему времени исследуются цели самых различных видов деятельности, например: профессиональной, трудовой, учебной, игровой, научной, творческой.

Определенный интерес для настоящего исследования представляет категория цели, раскрываемая педагогической наукой. Отражая функциональную роль цели, Бабанский Ю.К. видит цель в качестве исходного компонента педагогической деятельности и самого педагогического процесса, связывает ее (цель) с формированием у обучающихся системы научных наний, умений, навыков, мировоззрения, активной жизненной позиции личности, с развитием умений и навыков учебной деятельности, с психологией процесса [5]. Лихачев Б.Т. справедливо считает цель центральным звеном всякой педагогической системы, которая содержит в себе философские, экономические, политические, нравственные, правовые, эстетические, биологические представления о совершенном человеке и его представлении в общественной жизни. По структуре он выделяет следующие цели воспитания: цель-идеал, цель-стратегическая задача, цель-тактическая задача, цель-задача отражения устремлений различных национальных и социальных групп, цель-задача развития отдельной личности [6].

Несколько необычной для традиционного понимания представляется точка зрения В.А.Сластенина и А.И.Мищенко, которые выносят цель за непосредственные рамки педагогической системы, объясняя это пониманием цели как многоуровневого явления. Цель выступает и как предпосылка, и как внутренне присущее содержанию явление; в средствах цель также присутствует в явном и не явном виде, функционирует на уровне сознания и проявляется в деятельности. Авторы особо подчеркивают, что цель, будучи выражением социального заказа общества, интерпретируется в педагогических терминах, выступает в качестве систематизирующего фактора (не элемента), т.е., внешней 
силы по отношению к педагогической системе как таковой. Педагогическая система организуется с ориентацией на цель [7]. Одним из оснований формулирования целей воспитания в последнее время все чаще выступает система нравственных ценностей. На этот факт в свое время обратили внимание Никандров Н.Д., Сластенин В.А., Каширин В.П. и другие авторы. Так, Никандров Н.Д., например, пишет, что воспитание человека в духе этих ценностей и есть правильное решение проблемы целей воспитания [8].

В контексте предмета нашего исследования необходимым является рассмотрение нескольких целевых групп, прежде всего, целей экологического и социально-экологического образования, а также целей профессиональной подготовки. К настоящему времени достаточно четко определены цели экологического образования школьников (И.Д. Зверев, И.Т. Суравегина, А.Н. Захлебный и др.). По обоснованному мнению Суравегиной И.Т., главная цель экологического образования школьников - формирование экологической ответственности, предполагающей, с одной стороны, отношение к своему здоровью, с другой, отношение к окружающей среде: природной и социальной. Эта цель конкретизируется на каждом этапе обучения, имеет как мировоззренческую, так и научно-познавательную окраску, что осложняет процесс обучения и требует от учителя дальнейшей конкретизации задач [9].

Сформулированные цели носят общий характер, уточняясь по отдельным направлениям, в частности, социально-экологическому образованию школьников, разрабатываемого нами. Цель последнего предполагает формирование личности, готовой к установлению оптимальных отношений с природной средой на основе нормативного взаимодействия с ней, с учетом меры и способов рационального природопользования; повышение ее социально-экологической культуры (В.С. Шилова) [10].

Что касается системы профессиональной подготовки на ступени высшего образования, то и здесь ведется активный поиск целей экологического и социально-экологического образования. Так, цели экологического образования студентов связываются с экологическим 
императивом в процессе развития цивилизации и совершенствования человека (Егорова Г.И., Падерина М.А.); с формированием антропо-экологического, ценностного сознания и стиля мышления, общения и деятельности (Пак М.С. и др.); с экогуманитарной парадигмой (Груздева Н.В.) и др. [11].

Многие ученые, целью экологического образования в системе профессионального образования видят становление личности, ядром которой выступает экологическая культура, обеспечивающая разносторонность и гармоничность, целостное мировоззрение; преодоление отчужденности личности от природы и социума, экологическую ориентировку в макро- и микро среде (С.Н. Глазачев, Е.А. Когай и др.) [12].

Непосредственную связь профессионального и экологического образования устанавливает Н.М. Мамедов, справедливо считая, что в современных условиях научные знания должны помочь будущему специалисту не только разбираться в процессах и явлениях природы, сложных ситуациях жизни, но и действовать со знанием дела. Целью современного образования, подчеркивает автор, становится как усвоение основ наук, так и формирование методологических ориентаций и операционального мышления. Уточняя цели подготовки специалиста, Мамедов Н.М. указывает на их сложный характер, на необходимость формирования знаний, умений, навыков, нужных для принятия таких решений, которые не нарушают устойчивости социоэкосистем, содействуют сохранению природных систем, бережному отношению к ресурсам биосферы. Следует согласиться с Мамедовым Н.М. в определении цели-идеала, а именно - формирование человека экологичного [13].

Обозначенные общие цели экологического образования в системе подготовки специалиста не противоречат целям собственно профессионального образования. Так, Новиков А.М. одной из основных его целей видит создание условий овладения профессиональной деятельностью, получения квалификации (или переквалификации) для включения человека в общественно полезный труд в соответствии с его интересами и способностями [14]. Что касается процесса воспитания студентов, то его целью, по мнению Фокина Ю.Г., выступает формирование у студентов системы убеждений, 
нравственных норм и общекультурных качеств, предусмотренных получаемым образованием [15].

Подытоживая, отметим, что выделение этих целей связано, с одной стороны, с трудовой деятельностью, как процессом, совершающимся между обществом и природой; с другой - с личностными качествами, способствующими установлению гармоничных отношений с окружающей средой в процессе труда, позволяющими прогнозировать эти отношения в ближайшем и далеком будущем.

Таким образом, для определения целей социально-экологического образования студентов, как одного из основных видов деятельности, в настоящее время имеется достаточно предпосылок. Необходимым в этом случае является и выбор оснований для их формулирования. В настоящей работе в качестве такого основания была избрана система ценностей, принятых в обществе. Последнее является предметом дальнейшего нашего исследования.

\section{Список литературы}

1. Философский словарь. М., 1991;

2. Краткий социологический словарь. М., 1988;

3. Психология личности в трудах отечественных психологов. М., 2009.

4. Шадриков В.Д. Психология деятельности и способности человека. М., 1996.

5. Бабанский Ю.К. Оптимизация учебно-воспитательного процесса в школе. М., 1982.

6. Лихачев Б.Т. Педагогика. М., 2010.

7. Сластенин В.А., Мищенко В.И. Целостный педагогический процесс как объект профессиональной деятельности учителя. М., 1997.

8. Сластенин В.А., Каширин В.И. Психология и педагогика. М., 2001.

9. Суравегина И.Т. Учителю об экологическом образовании. М., 2003.

10. Шилова В.С. Социально-экологическое образование школьников: теория и практика. Монография. М.-Белгород, 1999; 2018.

11. Эколого-педагогическое образование: проблемы и перспективы развития.//Сборник материалов научно-практической конференции. Санкт-Петербург, 2001; Социально-экологическое образование учащейся молодежи Материалы Международной научно-практической 
конференции. Белгород, 2010; Экология, технологии, культура в современном мире. Материалы Международной конференции. М., 2010.

12.Глазачев С.Н., Когай Е.А. Экологическая культура и образование: очерки социальной экологии. М., 1999.

13. Мамедов Н.М. Культура, экология, образование. М., 1996.

14.Новиков А.М. Профессиональное образование в России. М., 1997.

15. Фокин Ю.Г. Преподавание и воспитание в высшей школе. М., 2002.

\section{References}

1. Filosofskiy slovar'. M., 1991.

2. Kratkiy sotsiologicheskiy slovar'. M., 1988.

3. Psikhologiya lichnosti v trudakh otechestvennykh psikhologov. M., 2009.

4. Shadrikov V.D. Psikhologiya deyatel'nosti i sposobnosti cheloveka. M., 1996.

5. Babanskiy Yu.K. Optimizatsiya uchebno-vospitatel'nogo protsessa v shkole. M., 1982.

6. Likhachev B.T. Pedagogika. M., 2010.

7. Slastenin V.A., Mishchenko V.I. Tselostnyy pedagogicheskiy protsess kak ob"ekt professional'noy deyatel'nosti uchitelya. M., 1997.

8. Slastenin V.A., Kashirin V.I. Psikhologiya i pedagogika. M., 2001.

9. Suravegina I.T.Uchitelyu ob ekologicheskom obrazovanii. M., 2003.

10. Shilova V.S. Sotsial'no-ekologicheskoe obrazovanie shkol'nikov: teoriya i praktika. Monografiya. M.-Belgorod, 1999; 2018.

11. Ekologo-pedagogicheskoe obrazovanie: problemy i perspektivy razvitiya.//Sbornik materialov nauchno-prakticheskoy konferentsii. Sankt-Peterburg, 2001; Sotsial'no-ekologicheskoe obrazovanie uchashcheysya molodezhi Materialy Mezhdunarodnoy nauchno-prakticheskoy konferentsii. Belgorod, 2010; Ekologiya, tekhnologii, kul'tura v sovremennom mire. Materialy Mezhdunarodnoy konferentsii.M., 2010.

12. Glazachev S.N., Kogay E.A. Ekologicheskaya kul'tura i obrazovanie: ocherki sotsial'noy ekologii. M., 1999.

13. Mamedov N.M. Kul'tura, ekologiya, obrazovanie. M., 1996.

14. Novikov A.M. Professional'noe obrazovanie v Rossii. M., 1997.

15. Fokin Yu.G. Prepodavanie i vospitanie v vysshey shkole.M., 2002. 